\title{
Toxoplasma gondii in cetaceans of Brazil: a histopathological and immunohistochemical survey
}

Toxoplasma gondii em cetáceos do Brasil: estudo histopatológico e imuno-histoquímico

Samira Costa-Silva ${ }^{1 *}$ (1); Carlos Sacristán ${ }^{1}$; Omar Gonzales-Viera²; Josué Díaz-Delgado';

Angélica María Sánchez-Sarmiento ${ }^{1}$; Juliana Marigo ${ }^{1}$; Kátia Regina Groch ${ }^{1}$; Vitor Luz Carvalho;

Ana Carolina Ewbank ${ }^{1}$; Adriana Castaldo Colosio ${ }^{4}$; Milton César Calzavara Marcondes ${ }^{4}$;

Ana Carolina Oliveira de Meirelles ${ }^{3}$; Carolina P. Bertozzi5; José Lailson-Brito ${ }^{6}$; Alexandre de Freitas Azevedo ${ }^{6}$; Valéria Ruoppolo $^{1}$; Larissa Oliveira ${ }^{7,8}$; Paulo Henrique Ott ${ }^{7,9}$; José Luiz Catão-Dias ${ }^{1}$

\footnotetext{
${ }^{1}$ Laboratório de Patologia Comparada de Animais Selvagens, Departamento de Patologia, Faculdade de Medicina Veterinária e Zootecnia, Universidade de São Paulo - USP, São Paulo, SP, Brasil

${ }^{2}$ Department of Pathology, Microbiology and Immunology, School of Veterinary Medicine, University of California, Davis, CA, USA

${ }^{3}$ Associação de Pesquisa e Preservação de Ecossistemas Aquáticos - AQUASIS, Caucaia, CE, Brasil

${ }^{4}$ Instituto Baleia Jubarte, Caravelas, BA, Brasil

${ }^{5}$ Biopesca, Instituto de Biociências, Universidade Estadual Paulista - UNESP, Campus do Litoral Paulista, São Vicente, SP, Brasil

${ }^{6}$ Laboratório de Mamíferos Aquáticos e de Bioindicadores "Profa Izabel M. G. do N. Gurgel” - MAQUA, Faculdade de Oceanografia, Universidade do Estado do Rio de Janeiro - UERJ, Rio de Janeiro, RJ, Brasil

${ }^{7}$ Grupo de Estudos de Mamíferos Aquáticos do Rio Grande do Sul - GEMARS, Torres, RS, Brasil

${ }^{8}$ Laboratório de Ecologia de Mamíferos, Universidade do Vale do Rio dos Sinos - UNISINOS, São Leopoldo, RS, Brasil

${ }^{9}$ Laboratório de Biodiversidade e Conservaçăo, Universidade Estadual do Rio Grande do Sul - UERGS, Unidade Litoral Norte, Osório, RS, Brasil
}

Received February 14, 2019

Accepted May 24, 2019

\begin{abstract}
Toxoplasmosis is a parasitic disease caused by the protozoan Toxoplasma gondii. In cetaceans, T. gondii infection is a significant cause of morbidity and mortality. Despite the worldwide range and broad cetacean host record of $T$. gondii infection, there is limited information on toxoplasmosis in cetaceans from the Southern hemisphere. We investigated the occurrence of $T$. gondii by histopathology and immunohistochemistry in tissue samples of 185 animals comprising 20 different cetacean species from Brazil. Three out of $185(1.6 \%)$ animals presented T. gondii-associated lesions: a captive killer whale Orcinus orca, a free-ranging common bottlenose dolphin Tursiops truncatus and a free-ranging Guiana dolphin Sotalia guianensis. The main lesions observed in these animals were necrotizing hepatitis, adrenalitis and lymphadenitis associated with protozoal cysts or extracellular tachyzoites presenting immunolabeling with anti- $T$. gondii antibodies. This study widens the spectrum of species and the geographic range of this agent in Brazil, and provides the first reports of T. gondii infection in a captive killer whale and in a free-ranging common bottlenose dolphin in South America.
\end{abstract}

Keywords: Toxoplasmosis, mortality, stranding, South America, protozoan infection, marine mammal.

\section{Resumo}

Toxoplasmose é uma doença parasitária causada pelo protozoário Toxoplasma gondii. A infecção por T. gondii é uma causa significativa de morbidade e mortalidade, nos cetáceos. Apesar da abrangência mundial e amplo registro de espécies de cetáceos infectadas por $T$. gondii, informaçóes sobre toxoplasmose em cetáceos do hemisfério sul são limitadas. Neste estudo pesquisou-se por meio de histopatologia e imuno-histoquímica a ocorrência de T. gondii em amostras de tecido de 185 animais, compreendendo 20 diferentes espécies de cetáceos que ocorrem no Brasil. Três dos 185 (1,6\%) animais apresentaram lesôes associadas a T. gondii: uma orca Orcinus orca mantida em cativeiro, um golfinho-nariz-de-garrafa

\footnotetext{
*Corresponding author: Samira Costa-Silva. Laboratório de Patologia Comparada de Animais Selvagens, Departamento de Patologia, Faculdade de Medicina Veterinária e Zootecnia, Universidade de São Paulo - USP, Av. Orlando Marques de Paiva, 87, Butantã, CEP 05508-270, São Paulo, SP, Brasil. e-mail: costasilva.samira@gmail.com
} 
Tursiops truncatus e um boto-cinza Sotalia guianensis de vida livre. As principais lesões observadas nesses animais foram hepatite, adrenalite e linfadenite necrotizantes associadas a cistos protozoários ou taquizoítos extracelulares, marcados com anticorpos anti- $T$. gondii. O presente estudo amplia o espectro de espécies susceptíveis a esse agente e o seu alcance geográfico no Brasil, fornecendo o primeiro relato da infecção por $T$. gondii em uma orca mantida em cativeiro e em um golfinho-nariz-de-garrafa de vida livre na América do Sul.

Palavras-chave: Toxoplasmose, mortalidade, encalhe, América do Sul, infecção por protozoários, mamífero marinho.

\section{Introduction}

Toxoplasma gondii is a zoonotic intracellular coccidian protozoan of the phylum Apicomplexa (DUBEY, 2008). This protozoan is one of the most common parasites of warm-blooded animals (DUBEY et al., 2004), and was described for the first time in Brazil and in Tunisia, in 1908 (NICOLLE \& MANCEAUX, 2009; SPLENDORE, 2009). The first record of toxoplasmosis in cetaceans was in a Guiana dolphin Sotalia guianensis from Rio de Janeiro state, Brazil, in the 1970's (BANDOLI \& OLIVEIRA, 1977). Since then, the exposure and infection by this protozoan has been detected through serological, pathological and molecular techniques in a wide variety of captive and free-ranging cetaceans worldwide (INSKEEP et al., 1990; OMATA et al., 2006; MAZZARIOL et al., 2012; GONZALES-VIERA et al., 2013; IQBAL et al., 2018). Most of these studies have covered individual cases or small groups of cetaceans (DI GUARDO et al., 2010; GONZALES-VIERA et al., 2013). Toxoplasmosis is a significant cause of morbidity and may lead to stranding and death, and is considered one of the most important emerging diseases in cetaceans worldwide (VAN BRESSEM et al., 2009; DI GUARDO et al., 2010; GONZALES-VIERA et al., 2013; BIGAL et al., 2018).

The epidemiology of T. gondii transmission has been established in several terrestrial animals (e.g., cats, livestock), and to a lesser extent, aquatic species (e.g., shellfish), including transplacental transmission in susceptible pregnant animals (TENTER et al., 2000; CATÁO-DIAS et al., 2013; JARDINE \& DUBEY, 2002; MILLER et al., 2008). In terrestrial animals, infection also occurs through ingestion of tissue cysts or contaminated food and/or water containing infecting sporulated oocysts released in feline feces. However, the transmission of T. gondii in cetaceans has not been fully elucidated. One major source of transmission in cetaceans could be the polluted marine environments in proximity with the coast, e.g., run-off of cat feces or soil contaminated with $T$. gondii oocysts from rivers, polluted effluents and ballast water from ships (VAN BRESSEM et al., 2009). In utero transmission of $T$. gondii has been described in Risso's dolphin Grampus griseus and Indo-Pacific bottlenose dolphin Tursiops aduncus (JARDINE \& DUBEY, 2002; RESENDES et al., 2002). For offshore marine ecosystems, T. gondii transmission patterns are still unclear.

The occurrence of T. gondii in marine mammals remains a poorly understood phenomenon, particularly in Brazil, where very limited information exists. Exposure to T. gondii was reported in Amazon river dolphins Inia geoffrensis (SANTOS et al., 2011), but to this date, only one cetacean species is known to be infected by $T$. gondii in Brazilian waters: the Guiana dolphin (BANDOLI \& OLIVEIRA, 1977; GONZALES-VIERA et al.,
2013). We hypothesized that $T$. gondii infection could be present in a wider number of cetacean species in Brazil than previous studies have suggested. Thus, the aim of this study was to evaluate retrospectively the occurrence of $T$. gondii infection in captive and free-ranging cetaceans employing histopathological and immunohistochemical (IHC) analyses on tissue samples obtained from a large marine mammal tissue bank in Brazil.

\section{Materials and Methods}

We evaluated formalin-fixed paraffin-embedded tissue samples stored at the Marine Mammal Tissue Bank of the Laboratory of Wildlife Comparative Pathology, School of Veterinary Medicine and Animal Science, University of São Paulo, Brazil. The samples included in the study came from partial or complete standard necropsies conducted on odontocetes and mysticetes between 1988 and 2014, provided by partner institutions attending marine mammal strandings, rehabilitation and incidental captures along the Brazilian coast. Tissues from 185 individuals of 20 different cetacean species (Table 1) were evaluated. Among the evaluated samples, three were from originally wild animals kept in captivity in two different amusement parks of the São Paulo state (Brazil): a killer whale Orcinus orca from Iceland kept in captivity in the 1980's, an Amazon river dolphin from the Amazon Basin, and a common bottlenose dolphin Tursiops truncatus of unknown origin. The remaining animals were all free-ranging species that stranded along the Brazilian coast, mostly from the southern region $(43.9 \%$; 80/182), followed by the southeastern $(30.2 \%$; $55 / 182)$, and northeastern $(25.8 \%$; 47/182) regions (Figure 1). The examined tissues were: liver, kidney, lung, spleen, skeletal muscle, lymph node, adrenal gland, brain, uterus, intestines, heart and eye.

Formalin-fixed paraffin-embedded tissue sections from the aforementioned organs were sectioned at $5 \mu \mathrm{m}$ thickness and stained with H\&E. Additionally, special histochemical techniques - periodic acid-Schiff (PAS), Giemsa and Grocott's methenamine silver stains - were used in selected tissue sections to improve visualization of protozoan structures compatible with $T$. gondii (LUNA, 1992; POPPER et al., 1960).

Immunohistochemical analysis for $T$. gondii was performed on selected tissues for which $T$. gondii has demonstrated tropism in cetaceans (i.e., liver, kidney, lung, brain and lymph nodes) (INSKEEP et al., 1990; MIKAELIAN et al., 2000; RESENDES et al., 2002; VAN BRESSEM et al., 2009; GONZALES-VIERA et al., 2013). Briefly, $3 \mu \mathrm{m}$-thick sections were deparaffinized and rehydrated through a series of graded 
Table 1. Cetacean species evaluated in Brazil for Toxoplasma gondii by immunohistochemistry.

\begin{tabular}{|c|c|c|c|c|}
\hline \multirow{2}{*}{ Species } & \multirow{2}{*}{$\begin{array}{l}\text { Number of } \\
\text { individuals }\end{array}$} & \multicolumn{3}{|c|}{ Sex ${ }^{b}$} \\
\hline & & $\mathbf{M}$ & $\mathbf{F}$ & $\mathbf{U}$ \\
\hline Franciscana dolphin (Pontoporia blainvillei) & 102 & 57 & 41 & 4 \\
\hline Guiana dolphin (Sotalia guianensis) ${ }^{\mathrm{a}}$ & 27 & 14 & 11 & 2 \\
\hline Dwarf sperm whale (Kogia sima) & 7 & 4 & 3 & 0 \\
\hline Atlantic spotted dolphin (Stenella frontalis) & 6 & 6 & 0 & 0 \\
\hline Spinner dolphin (Stenella longirostris) & 5 & 4 & 1 & 0 \\
\hline Clymene dolphin (Stenella clymene) & 6 & 3 & 3 & 0 \\
\hline Common bottlenose dolphin (Tursiops truncatus) ${ }^{\mathrm{a}}$ & 4 & 2 & 1 & 1 \\
\hline Melon-headed whale (Peponocephala electra) & 5 & 3 & 2 & 0 \\
\hline Rough-toothed dolphin (Steno bredanensis) & 3 & 2 & 1 & 0 \\
\hline Short-finned pilot whale (Globicephala macrorhynchus) & 3 & 3 & 0 & 0 \\
\hline Sperm whale (Physeter macrocephalus) & 3 & 1 & 2 & 0 \\
\hline Pygmy sperm whale (Kogia breviceps) & 2 & 2 & 0 & 0 \\
\hline Humpback whale (Megaptera novaeangliae) & 2 & 2 & 0 & 0 \\
\hline Fraser's dolphin (Lagenodelphis hosei) & 2 & 0 & 2 & 0 \\
\hline Striped dolphin (Stenella coeruleoalba) & 2 & 0 & 2 & 0 \\
\hline Killer whale (Orcinus orca $)^{\mathrm{a}}$ & 2 & 1 & 1 & 0 \\
\hline Short-beaked common dolphin (Delphinus delphis) & 1 & 1 & 0 & 0 \\
\hline Risso’s dolphin (Grampus griseus) & 1 & 0 & 1 & 0 \\
\hline Gervais' beaked whale (Mesoplodon europaeus) & 1 & 0 & 1 & 0 \\
\hline Amazon river dolphin (Inia geoffrensis) & 1 & 0 & 0 & 1 \\
\hline TOTAL & 185 & 105 & 72 & 8 \\
\hline
\end{tabular}

${ }^{a}$ Species with positive results; ${ }^{\mathrm{b}} \mathrm{M}=$ male; $\mathrm{F}=$ female; $\mathrm{U}=$ unknown.

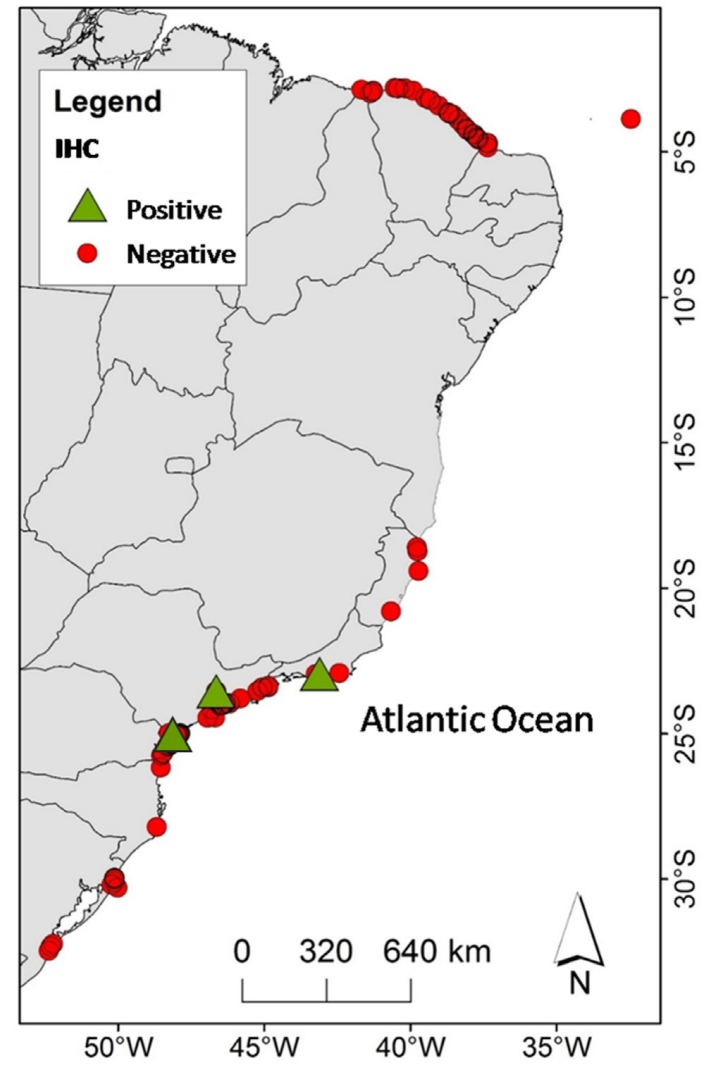

Figure 1. Geographic distribution along the coastline of Brazil of Toxoplasma gondii- positive (green triangle) and -negative (red circle) animals, according to immunohistochemistry. alcohols. Toxoplasma gondii antigen was retrieved by heating tissue sections in citrate buffer $(\mathrm{pH}=7.0)$ solution for seven minutes at $90{ }^{\circ} \mathrm{C}$. The sections were blocked with $1 \%$ normal rabbit serum in PBS for 30 minutes followed by overnight incubation with a polyclonal goat anti-T. gondii primary antibody (1 in 400 dilution; VMRD Inc; Pullman). This antibody does not cross-react with Neospora caninum (CORBELLINI et al., 2002). The sections were washed in PBS and incubated for 30 minutes with biotinylated polyclonal anti-goat secondary antibody (1 in 600 dilution; Dako) as previously described (DI GUARDO et al., 2010). Amplification of the immunologic reaction was based on an avidin-biotin-peroxidase complex method (Elite ABC kit, Vector laboratories), following manufacturer's instructions. Labeling was 'visualized' with 3-amino-9-ethyl-carbazole (Sigma) and/or diaminobenzidine (DAB D-5637; Sigma), and sections were counterstained with Mayer's haematoxylin. Tissue sections in which the primary antibodies were replaced by phosphate buffered saline or nonimmune homologous serum served as negative controls. Sections of the adrenal gland of a Guiana dolphin infected by $T$. gondii (GONZALES-VIERA et al., 2013) were used as positive control. Morbillivirus immunohistochemistry was also performed on selected tissue sections of T. gondii positive cases to rule out potential coinfection, following a previously published protocol (SALIKI et al., 2002; GROCH et al., 2014), using a commercial monoclonal antibody against the nucleoprotein of Canine distemper virus (VMRD Inc.), known to cross-react with Cetacean morbillivirus. Positive tissue samples of an infected Guiana dolphin were selected as positive control (GROCH et al., 2014). 


\section{Results}

Three of 185 (1.6\%) animals were IHC-positive for T. gondii-: a captive killer whale, a free-ranging common bottlenose dolphin, and a free-ranging Guiana dolphin. These animals presented a variety of toxoplasmosis-compatible lesions, with positively labeled protozoal cysts and free tachyzoites. The occurrence of T. gondii in free-ranging species was $1.1 \%(2 / 182)$, whereas the occurrence in captive animals was $33.3 \%(1 / 3)$. A summary of
T. gondii-associated lesions in these animals follows. Additional information regarding the microscopic findings of positive animals is available in Table 2. All three T. gondii positive animals were IHC-negative for morbillivirus. No PCR techniques were employed in these cases because frozen tissue samples were not available.

Case No 1 (MM\#452) was a 5-6 years-old juvenile $(2,500 \mathrm{~kg})$ male killer whale captured in Iceland in 1983, and one year later brought into an oceanarium located in the city of São Paulo, São Paulo state, Brazil. The animal remained in this facility until its

Table 2. Microscopic lesions in Toxoplasma gondii-positive animals in Brazil.

\begin{tabular}{ll}
\hline \multirow{2}{*}{ Organ } & \multicolumn{1}{c}{ Case 1 (killer whale) } \\
\cline { 2 - 2 } Liver & $\begin{array}{l}\text { Moderate randomly multifocal to } \\
\text { coalescent necrotizing hepatitis with } \\
\text { protozoan cysts, compatible with } \\
\text { T. gondii. T. gondii-positive by IHC. }\end{array}$ \\
& \\
Kidney & $\begin{array}{l}\text { Acute multifocal interstitial nephritis } \\
\text { with mild to moderate mixed infiltrate, } \\
\text { mild to moderate membranous } \\
\text { glomerulonephritis. }\end{array}$
\end{tabular}

Adrenal gland

NA

NA

Lung

Stomach

Intestine

Muscle

Thyroid

Lymph node

Moderate to marked multifocal acute fibrinosuppurative and hemorrhagic bronchopneumonia with protozoan cysts (compatible with T. gondii) and bacteria. T. gondii-positive by IHC.

Mild to moderate multifocal to coalescent granulocytic gastritis.

Mild to moderate multifocal granulocytic lymphadenitis, mild to moderate diffuse mixed enteritis with crypt microabscesses (cryptitis).

Mild multifocal acute segmental myocyte degeneration and necrosis.

Mild multifocal to coalescent

lymphoplasmacytic thyroiditis.

Marked necrosuppurative lymphadenitis with protozoal cysts (compatible with T. gondii), and lymphoid depletion with lymphocytolysis. T. gondii-positive by IHC. with hemorrhage.
Microscopic lesions

Case 2 (common bottlenose dolphin)

Moderate to marked randomly

multifocal to coalescent necrotizing

hepatitis with protozoan cysts,

compatible with $T$. gondii, and

predominantly mononuclear

infiltrate, mild hepatic congestion and

hemorrhage. T. gondii-positive by IHC.

Mild multifocal chronic tubular ectasia and glomerular cyst formation.

NA

Case 3 (Guiana dolphin) NA adrenalitis associated with numerous round to oval protozoal cysts and extracellular tachyzoites compatible with T. gondii. T. gondii-positive by IHC.

Moderate to marked multifocal acute NA fibrinosuppurative bronchopneumonia 
death, on March $7^{\text {th }}$, 1988. No clinical data were available. Samples of lungs, liver, spleen, kidneys, skeletal muscle, glandular stomach, large intestine, thyroid glands, and lymph nodes were collected upon necropsy. The only reported macroscopic finding was a renal cyst. Microscopically, the main lesions included moderate to marked, multifocal, acute fibrinosuppurative and hemorrhagic bronchopneumonia with protozoan cysts, moderate randomly multifocal to coalescent necrotizing hepatitis with protozoan cysts (compatible with T. gondii), marked necrosuppurative lymphadenitis, acute multifocal interstitial nephritis with mild-moderate mixed infiltrate, mild to moderate, multifocal, chronic membranous glomerulonephritis, and acute fibrinoid vasculitis.

Case No 2 (MM\#178) was a juvenile male common bottlenose dolphin of $2.43 \mathrm{~m}$ total body length, that stranded alive and died shortly after stranding, on October $29^{\text {th }}, 2001$, in Lagos Region, Rio de Janeiro state, Brazil (22 56 'S, $\left.42^{\circ} 19^{\prime} \mathrm{W}\right)$. Samples of lungs, liver, kidneys, and large intestine were collected upon necropsy. No gross findings were reported. The main microscopic findings observed were moderate to severe, multifocal random to coalescing necrotizing hepatitis with protozoan cysts compatible with $T$. gondii and moderate to marked, multifocal, acute fibrinosuppurative bronchopneumonia.

Case No 3 (MM\#67) was a 1.86 m-long adult, female Guiana dolphin that stranded dead on March $3^{\text {th }}, 1998$, in Paranaguá Bay, Paraná state, Brazil (2531'S, $\left.48^{\circ} 30^{\prime} \mathrm{W}\right)$. No necropsy records were available. Samples of eye and adrenal glands were evaluated. Microscopically, the main finding was marked, multifocal, acute necrotizing adrenalitis with numerous protozoal cysts and extracellular tachyzoites compatible with T. gondii, and further highlighted with PAS and Giemsa stains.

\section{Discussion}

Despite the widespread geographical range of $T$. gondii infection, in Brazil, the current knowledge regarding cetacean toxoplasmosis is limited to few species and studies (BANDOLI \& OLIVEIRA, 1977; SANTOS et al., 2011; GONZALES-VIERA et al., 2013). Based on microscopical and immunohistochemical examinations, we provide the first description of $T$. gondii in a common bottlenose dolphin of South America, and in a captive killer whale. Furthermore, the identification of toxoplasmosis in a Guiana dolphin corroborates with previous observations regarding this species and geographic area, the Paranaguá Bay. On the other hand, in spite of the high prevalence of T. gondii antibodies reported in free-ranging Amazon river dolphins (SANTOS et al., 2011), our sampled captive Amazon river dolphin was $T$. gondii- negative.

We detected protozoal cysts and free tachyzoites of $T$. gondii by IHC and observed histological changes within multiorgan necroinflammatory foci, e.g., necrotizing hepatitis, necrosuppurative lymphadenitis (killer whale), necrotizing hepatitis (common bottlenose dolphin), and necrotizing adrenalitis (Guiana dolphin). These lesions are in agreement with previous reports of $T$. gondii infection in odontocetes (CRUICKSHANK et al., 1990; RESENDES et al., 2002; DI GUARDO \& MAZZARIOL, 2013) and mysticetes (MAZZARIOL et al., 2012). The main lesions observed in cetacean cases of toxoplasmosis are necrotizing hepatitis, lymphadenitis and lymphoid necrosis, interstitial pneumonia, adrenal necrosis, and non-suppurative encephalitis and meningoencephalitis with bradyzoites and free tachyzoites (INSKEEP et al., 1990; MIGAKI et al., 1990; MIKAELIAN et al., 2000; RESENDES et al., 2002; VAN BRESSEM et al., 2009; GONZALES-VIERA et al., 2013; ROE et al., 2013). In T. gondii-positive cases, all tested tissues were negative for morbillivirus, suggesting that $T$. gondii possibly acted as a primary agent, as previously observed (DI GUARDO et al., 2010; GONZALES-VIERA et al., 2013; ROE et al., 2013). The scarce number of brain samples available for this study ( $\mathrm{n}=4$ ) probably prevented the identification of T. gondii-associated lesions in nervous tissue, which is commonly involved in cetacean toxoplasmosis cases (DI GUARDO et al., 2010; SIERRA et al., 2014).

In this study, we evaluated cetacean samples from geographic areas that correspond to a large portion of the Brazilian coastline, most of them coastal species, mainly franciscanas (Pontoporia blainvillei) (55.0\%) and Guiana dolphins (14.5\%). Coastal cetaceans, considered suitable sentinels of the marine environmental ecosystem and important indicators of marine pollution, are usually more exposed to anthropogenic activities (WELLS et al., 2004; BOSSART, 2011; MOURA et al., 2014). From these, we found histological and immunohistochemical evidences of toxoplasmosis in one Guiana dolphin. This is the third report of toxoplasmosis in this species (BANDOLI \& OLIVEIRA, 1977; GONZALES-VIERA et al., 2013). This animal presented severe adrenalitis, similar to what was reported by Gonzales-Viera et al. (2013) in another Guiana dolphin from the same area (Paranaguá Bay) that died in the same year (1998). Given the marked pattern of site fidelity presented by Guiana dolphins (MOURA et al., 2014), this result suggests a common source of exposure to T. gondii and a possible negative impact of toxoplasmosis on this population. Although the low occurrence of $T$. gondii infection found in the present study does not allow us to infer further on this protozoan's geographic distribution, the location of the Guiana dolphin case and previous reports suggest that infection may occur at higher rates in coastal areas of Brazil. Coastal areas usually receive freshwater run-offs and terrestrial biologic pollutants, contributing to the presence of T. gondii (SHAPIRO et al., 2015). These results also suggest areas in which future research efforts should be concentrated.

Concerning killer whales, positive serology for $T$. gondii was reported in a killer whale calf that stranded alive in Japan, in 1988 (MURATA et al., 2004), and T. gondii infection was identified by molecular techniques in a stranded killer whale from the Northeastern Pacific, in California (GIBSON et al., 2011). However, these reports lacked detailed pathological examinations. In the present study, we provide the first histopathological and immunohistochemical evidences of toxoplasmosis in this species. Based on the severity and extent of characteristic multiorganic necroinflammatory foci, we believe that $T$. gondii played a major role in the death of the evaluated killer whale. In this case, potential environmental sources of $T$. gondii infectious forms may include water and/or food contamination in one or more of the following scenarios: (1) the facility's water system (e.g., used to clean fish and the enclosure, and fill the tank), especially considering that sporulated oocysts of $T$. gondii are viable in saltwater for at least 


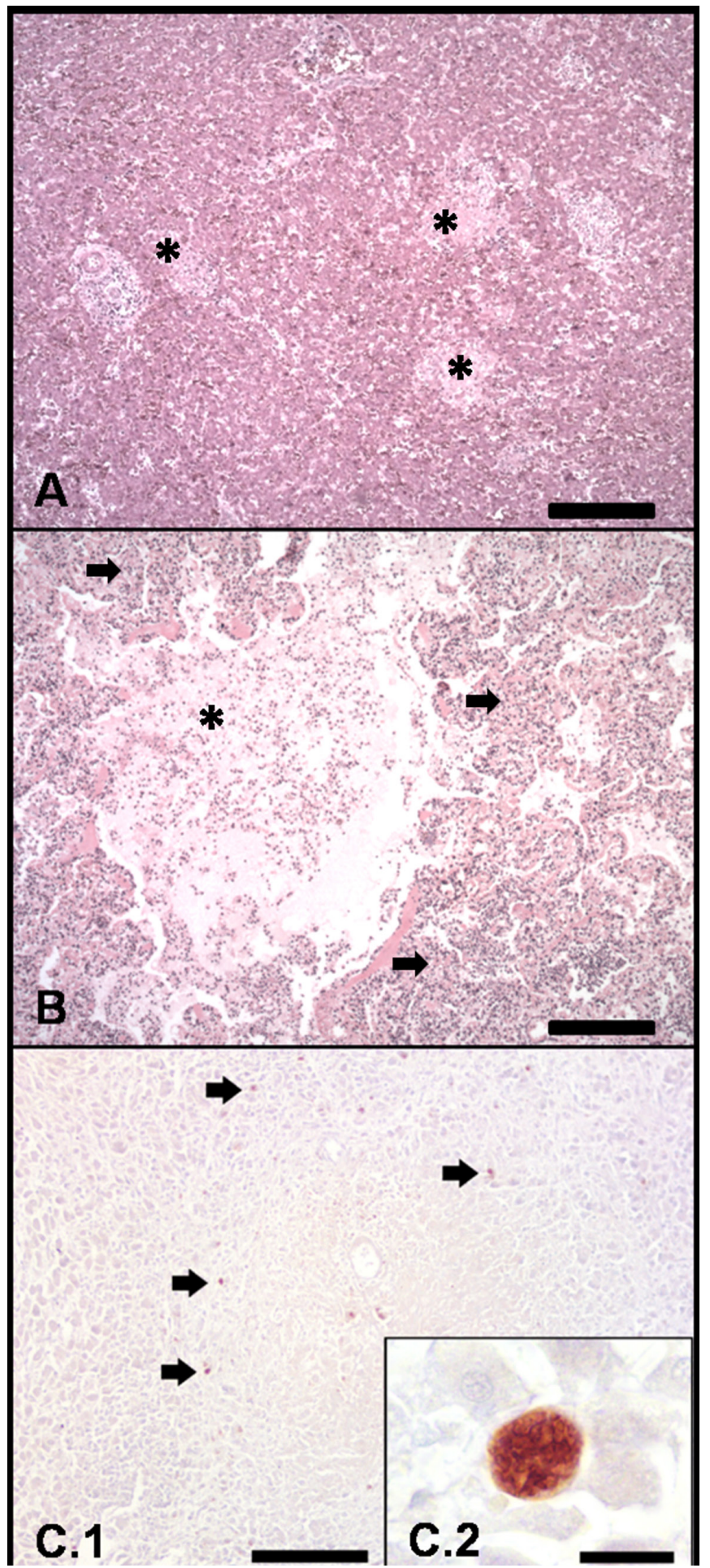

Figure 2. Microscopic lesions and immunohistochemical findings in Toxoplasma gondii positive animals. (A) Atlantic bottlenose dolphin (Tursiops truncatus). Liver, necrotizing hepatitis (asterisk), H\&E, scale bar $=200 \mu \mathrm{m}$; (B) Killer whale (Orcinus orca). Lung, bronchopneumonia (arrows) with alveolar infiltrate (asterisk), H\&E, scale bar = $200 \mu \mathrm{m}$; (C.1) Guiana dolphin (Sotalia guianensis). Adrenal gland, there is focally extensive lytic necrosis with multiple protozoal cysts (arrows). IHC for T. gondii, Mayer's hematoxylin counterstaining, scale bar $=500 \mu \mathrm{m}$; (C.2) Detailed view of T. gondii protozoal cyst containing numerous bradyzoites. IHC for T. gondii, Mayer's hematoxylin counterstaining, scale bar $=25 \mu \mathrm{m}$. two years (AUBERT \& VILLENA, 2009); (2) contaminated food (e.g., fish); and (3) contaminated enclosure (e.g., contaminated fomites, personnel and/or presence of roaming cats). These findings highlight the importance of proper hygiene and husbandry in captive cetaceans, including properly treated water and reliable food sources free of $T$. gondii sporulated oocysts. Although unlikely, considering the physiopathology of toxoplasmosis in highly susceptible or 'less adapted' hosts (CATÃO-DIAS et al., 2013) - which could be the case for the killer whale - one should also consider the possibility of infection prior to the specimen's capture in the wild (e.g., transplacental or transmammary) or initial period in captivity (1984-1988). In that case, the infection would have been quiescent until being activated by the stress of captivity and/or other predisposing factors (e.g., concomitant diseases) (LINDSAY et al., 2003; AUBERT \& VILLENA, 2009; MAZZARIOL et al., 2012).

Toxoplasma gondii infections in common bottlenose dolphins have been observed worldwide; in the Mediterranean Sea and the Atlantic Ocean (CRUICKSHANK et al., 1990; INSKEEP et al., 1990; DI GUARDO et al., 1995; DUBEY et al., 2008; PRETTI et al., 2010; PROFETA et al., 2015; BIGAL et al., 2018), and also in captive specimens (DUBEY et al., 2009). Furthermore, it has also been detected in a related species from the Pacific Ocean - the Indo-Pacific bottlenose dolphin (JARDINE \& DUBEY, 2002). However, this is the first report of T. gondii in an Atlantic bottlenose dolphin from South America (Figure 2), widening the geographic range of $T$. gondii occurrence for this species.

Because cetacean species' susceptibility to $T$. gondii infection is unknown, non-exposure and natural resistance to this agent should be considered in negative cases (DI GUARDO \& MAZZARIOL, 2013). Omata et al. (2006) proposed that killer whales from Japan might be resistant to $T$. gondii; however, the evidence provided seemed slight because none of these animals presented antibodies against the agent.

Finally, this is the first report of a large-scale $T$. gondii survey based on histopathological and immunohistochemical examinations in cetaceans of Brazil. This study widens the spectrum of T. gondii-susceptible species and geographic range of this agent in Brazil and presents the first report of T. gondii-infection in a captive killer whale, and in a free-ranging Atlantic bottlenose dolphin from South America. Furthermore, it corroborates with previous observations of toxoplasmosis in Guiana dolphin and the geographic area of Paranaguá Bay. Further studies are warranted to characterize the circulating strains and clarify the distribution of this protozoan, its transmission route(s), unsolved pathogenetic mechanisms, cetacean host-specific susceptibilities and potential implications to the conservation of cetacean species of Brazil and mechanisms involved in human exposure.

\section{Acknowledgements}

We thank Leonardo L. Wedekin, Jorge Oyakawa and Sândara Sguario for their technical support. We also thank the Aquário de Santos, Associação de Pesquisa e Preservação de Ecossistemas Aquáticos (AQUASIS), Instituto Baleia Jubarte, Instituto de Pesquisas de Cananéia (IPeC), Grupo de Estudos de Mamíferos 
Aquáticos do Rio Grande do Sul (GEMARS) Laboratório de Mamíferos Aquáticos e Bioindicadores 'Profa. Izabel Gurgel' Faculdade de Oceanografia - Universidade do Estado do Rio de Janeiro (MAQUA), Museu Oceanográfico da FURG, Playcenter, Projeto Biopesca - Universidade Estadual Paulista-UNESP, and Projeto Baleia Franca/Instituto Australis for providing the samples and necropsy records. This study was co-financed by CAPES and FAPESP. The financial sources had no influence over the project's development. All procedures were performed in accordance with the Ethical Committee of the School of Veterinary Medicine and Animal Sciences, University of São Paulo (process number: 2551070144). JDD is the recipient of a post-doctoral fellowship by FAPESP (grant \#2017/02223-8), and CNPq provided scholarship to J.L.C.-D (grant \#305349/2015-5).

\section{References}

Aubert D, Villena I. Detection of Toxoplasma gondii oocysts in water: proposition of a strategy and evaluation in Champagne-Ardenne region, France. Mem Inst Oswaldo Cruz 2009; 104(2): 290-295. http://dx.doi. org/10.1590/S0074-02762009000200023. PMid:19430655.

Bandoli JG, Oliveira CAB. Toxoplasmose em Sotalia guianensis (Van Beneden, 1863, Cetacea-Delphinidae). Folha Med 1977; 75(4): 459-468.

Bigal E, Morick D, Scheinin AP, Salant H, Berkowitz A, King R, et al. Detection of Toxoplasma gondii in three common bottlenose dolphins (Tursiops truncatus): a first description from the Eastern Mediterranean Sea. Vet Parasitol 2018; 258: 74-78. http://dx.doi.org/10.1016/j. vetpar.2018.06.009. PMid:30105982.

Bossart GD. Marine mammals as sentinel species for oceans and human health. Vet Pathol 2011; 48(3): 676-690. http://dx.doi. org/10.1177/0300985810388525. PMid:21160025.

Catão-Dias ZL, Epiphanio S, Kierulff MCM. Neotropical primates and their susceptibility to Toxoplasma gondii: new insights of an old problem. In: Brinkworth JF, Pechenkina K, editors. Primates, pathogens, and evolution. New York: Springer Press; 2013. p. 253-289. http://dx.doi. org/10.1007/978-1-4614-7181-3_9.

Corbellini LG, Driemeier D, Cruz CFE, Gondim LFP, Wald V. Neosporosis as a cause of abortion in dairy cattle in Rio Grande do Sul, southern Brazil. Vet Parasitol 2002; 103(3): 195-202. http://dx.doi.org/10.1016/ S0304-4017(01)00600-8. PMid:11750112.

Cruickshank JJ, Haines DM, Palmer NC, St Aubin DJ. Cysts of a Toxoplasma-like organism in an Atlantic bottlenose dolphin. Can Vet J 1990; 31(3): 213-215. PMid:17423539.

Di Guardo G, Agrimi U, Morelli L, Cardeti G, Terracciano S, Kennedy S. Post mortem investigations on cetaceans found stranded on the coasts of Italy between 1990 and 1993. Vet Rec 1995; 136(17): 439-442. http:// dx.doi.org/10.1136/vr.136.17.439. PMid:7631479.

Di Guardo G, Mazzariol S. Toxoplasma gondii: clues from stranded dolphins. Vet Pathol 2013; 50(5): 737. http://dx.doi.org/10.1177/0300985813486816. PMid:24014612.

Di Guardo G, Proietto U, Di Francesco CE, Marsilio F, Zaccaroni A, Scaravelli D, et al. Cerebral toxoplasmosis in striped dolphins (Stenella coeruleoalba) stranded along the Ligurian Sea coast of Italy. Vet Pathol 2010; 47(2): 245-253. http://dx.doi.org/10.1177/0300985809358036. PMid:20118319.
Dubey JP, Fair PA, Sundar N, Velmurugan G, Kwok OC, McFee WE, et al. Isolation of Toxoplasma gondii from bottlenose dolphins (Tursiops truncatus). J Parasitol 2008; 94(4): 821-823. http://dx.doi. org/10.1645/GE-1444.1. PMid:18576793.

Dubey JP, Lipscomb TP, Mense M. Toxoplasmosis in an elephant seal (Mirounga angustirostris). J Parasitol 2004; 90(2): 410-411. http://dx.doi. org/10.1645/GE-155R. PMid:15165069.

Dubey JP, Mergl J, Gehring E, Sundar N, Velmurugan GV, Kwok OC, et al. Toxoplasmosis in captive dolphins (Tursiops truncatus) and walrus (Odobenus rosmarus). J Parasitol 2009; 95(1): 82-85. http://dx.doi. org/10.1645/GE-1764.1. PMid:19245284.

Dubey JP. The history of Toxoplasma gondii - The first 100 years. J Eukaryot Microbiol 2008; 55(6): 467-475. http://dx.doi.org/10.1111/j.15507408.2008.00345.x. PMid:19120791.

Gibson AK, Raverty S, Lambourn DM, Huggins J, Magargal SL, Grigg ME. Polyparasitism is associated with increased disease severity in Toxoplasma gondii-infected marine sentinel species. PLoS Negl Trop Dis 2011; 5(5): e1142. http://dx.doi.org/10.1371/journal.pntd.0001142. PMid:21629726.

Gonzales-Viera O, Marigo J, Ruoppolo V, Rosas FCW, Kanamura CT, Takakura C, et al. Toxoplasmosis in a Guiana dolphin (Sotalia guianensis) from Paraná, Brazil. Vet Parasitol 2013; 191(3-4): 358-362. http://dx.doi. org/10.1016/j.vetpar.2012.09.012. PMid:23063774.

Groch KR, Colosio AC, Marcondes MCC, Zucca D, Díaz-Delgado J, Niemeyer C, et al. Novel cetacean morbillivirus in Guiana dolphin, Brazil. Emerg Infect Dis 2014; 20(3): 511-513. http://dx.doi.org/10.3201/ eid2003.131557. PMid:24565559.

Inskeep W 2nd, Gardiner CH, Harris RK, Dubey JP, Goldston RT. Toxoplasmosis in Atlantic bottle-nosed dolphins (Tursiops truncatus). J Wildl Dis 1990; 26(3): 377-382. http://dx.doi.org/10.7589/0090-355826.3.377. PMid:2388360.

Iqbal A, Measures L, Lair S, Dixon B. Toxoplasma gondii in stranded St. Lawrence Estuary beluga Delphinapterus leucas in Quebec, Canada. Dis Aquat Organ 2018; 130(3): 165-175. http://dx.doi.org/10.3354/ dao03262. PMid:30259869.

Jardine JE, Dubey JP. Congenital toxoplasmosis in a Indo-Pacific bottlenose dolphin (Tursiops aduncus). J Parasitol 2002; 88(1): 197-199. http://dx.doi.org/10.1645/0022-3395(2002)088[0197:CTIAIP]2.0. CO;2. PMid:12053968.

Lindsay DS, Collins MV, Mitchell SM, Cole RA, Flick GJ, Wetch $\mathrm{CN}$, et al. Sporulation and survival of Toxoplasma gondii oocysts in seawater. J Eukaryot Microbiol 2003;50(s1 Suppl): 687-688. http:// dx.doi.org/10.1111/j.1550-7408.2003.tb00688.x. PMid:14736220.

Luna LG. Histopathologic methods and color atlas of special stains and tissue artifacts. Gaithersburg: America Histolabs; 1992.

Mazzariol S, Marcer F, Mignone W, Serracca L, Goria M, Marsili L, et al. Dolphin morbillivirus and Toxoplasma gondii coinfection in a Mediterranean fin whale (Balaenoptera physalus). BMC Vet Res 2012; 8(1): 20. http:// dx.doi.org/10.1186/1746-6148-8-20. PMid:22397492.

Migaki G, Sawa TR, Dubey JP. Fatal disseminated toxoplasmosis in a Spinner dolphin (Stenella longirostris). Vet Pathol 1990; 27(6): 463-464. http://dx.doi.org/10.1177/030098589902700615. PMid:2278137.

Mikaelian I, Boisclair J, Dubey JP, Kennedy S, Martineau D. Toxoplasmosis in beluga whales (Delphinapterus leucas) from St Lawrence Estuary: two case reports and a serological survey. J Comp Pathol 2000; 122(1): 73-76. http://dx.doi.org/10.1053/jcpa.1999.0341. PMid:10627393. 
Miller M, Conrad P, James ER, Packham A, Toy-Choutka S, Murray MJ, et al. Transplacental toxoplasmosis in a wild southern sea otter (Enhydra lutris nereis). Vet Parasitol 2008; 153(1-2): 12-18. http://dx.doi. org/10.1016/j.vetpar.2008.01.015. PMid:18304737.

Moura JF, Hauser-Davis RA, Lemos L, Emin-Lima R, Siciliano S. Guiana dolphins (Sotalia guianensis) as marine ecosystem sentinels: ecotoxicology and emerging diseases. Rev Environ Contam Toxicol 2014; 228: 1-29. http://dx.doi.org/10.1007/978-3-319-01619-1_1. PMid:24162090.

Murata K, Mizuta K, Imazu K, Terasawa F, Taki M, Endoh T. The prevalence of Toxoplasma gondii antibodies in wild and captive cetaceans from Japan. J Parasitol 2004; 90(4): 896-898. http://dx.doi.org/10.1645/ GE-197R. PMid:15357097.

Nicolle MC, Manceaux L. On a new protozoan in gundis (Toxoplasma N. Gen). Mem Inst Oswaldo Cruz 2009; 104: 1-3.

Omata Y, Umeshita Y, Watarai M, Tachibana M, Sasaki M, Murata K, et al. Investigation for presence of Neospora caninum, Toxoplasma gondii and Brucella-species infection in killer whales (Orcinus orca) mass-stranded on the coast of Shiretoko, Hokkaido, Japan. J Vet Med Sci 2006; 68(5): 523-526. http://dx.doi.org/10.1292/jvms.68.523. PMid:16757901.

Popper H, Paronetto F, Barka T. PAS-positive structures of nonglycogenic character in normal and abnormal liver. Arch Pathol 1960; 70: 300-313. PMid:14434186.

Pretti C, Mancianti F, Nardoni S, Ariti G, Monni G, Di Bello D, et al. Detection of Toxoplasma gondii infection in dolphins stranded along the Tuscan coast, Italy. Rev Med Vet 2010; 161(10): 428-431.

Profeta F, Di Francesco CE, Marsilio F, Mignone W, Di Nocera F, De Carlo E, et al. Retrospective seroepidemiological investigations against morbillivirus, Toxoplasma gondii and Brucella spp. in cetaceans stranded along the Italian coastline (1998-12014). Res Vet Sci 2015; 101: 89-92. http://dx.doi.org/10.1016/j.rvsc.2015.06.008. PMid:26267096.

Resendes AR, Almería S, Dubey JP, Obón E, Juan-Sallés C, Degollada E, et al. Disseminated toxoplasmosis in a Mediterranean pregnant Risso's dolphin (Grampus griseus) with transplacental fetal infection. J Parasitol 2002; 88(5): 1029-1032. http://dx.doi.org/10.1645/00223395(2002)088[1029:DTIAMP]2.0.CO;2. PMid:12435153.
Roe WD, Howe L, Baker EJ, Burrows L, Hunter SA. An atypical genotype of Toxoplasma gondii as a cause of mortality in Hector's dolphins (Cephalorhynchus hectori). Vet Parasitol 2013; 192(1-3): 67-74. http:// dx.doi.org/10.1016/j.vetpar.2012.11.001. PMid:23207018.

Saliki JT, Cooper EJ, Gustavson JP. Emerging morbillivirus infections of marine mammals: development of two diagnostic approaches. Ann NYAcad Sci 2002; 969(1): 51-59. http://dx.doi.org/10.1111/j.1749-6632.2002. tb04350.x. PMid:12381563.

Santos PS, Albuquerque GR, Da Silva VMF, Martin AR, Marvullo MFV, Souza SLP, et al. Seroprevalence of Toxoplasma gondii in free-living Amazon River dolphins (Inia geoffrensis) from central Amazon, Brazil. Vet Parasitol 2011; 183(1-2): 171-173. http://dx.doi.org/10.1016/j. vetpar.2011.06.007. PMid:21764516.

Shapiro K, VanWormer E, Aguilar B, Conrad PA. Surveillance for Toxoplasma gondii in California mussels (Mytilus californianus) reveals transmission of atypical genotypes from land to sea. Environ Microbiol 2015; 17(11): 4177-4188. http://dx.doi.org/10.1111/1462-2920.12685. PMid:25367256.

Sierra E, Sánchez S, Saliki JT, Blas-Machado U, Arbelo M, Zucca D, et al. Retrospective study of etiologic agents associated with nonsuppurative meningoencephalitis in stranded cetaceans in the Canary Islands. J Clin Microbiol 2014; 52(7): 2390-2397. http://dx.doi.org/10.1128/ JCM.02906-13. PMid:24759718.

Splendore A. A new protozoan parasite of rabbit found in histological lesions similar to human Kala-Azar. Mem Inst Oswaldo Cruz 2009; 104: 1-2.

Tenter AM, Heckeroth AR, Weiss LM. Toxoplasma gondii: from animals to humans. Int J Parasitol 2000; 30(12-13): 1217-1258. http://dx.doi. org/10.1016/S0020-7519(00)00124-7. PMid:11113252.

Van Bressem MF, Raga JA, Di Guardo G, Jepson PD, Duignan PJ, Siebert $\mathrm{U}$, et al. Emerging infectious diseases in cetaceans worldwide and the possible role of environmental stressors. Dis Aquat Organ 2009; 86(2): 143-157. http://dx.doi.org/10.3354/dao02101. PMid:19902843.

Wells RS, Rhinehart HL, Hansen LJ, Sweeney JC, Townsend FI, Stone $\mathrm{R}$, et al. Bottlenose dolphins as marine ecosystem sentinels: developing health monitoring system. EcoHealth 2004; 1(3): 246-254. http://dx.doi. org/10.1007/s10393-004-0094-6. 